\title{
THE NATIONAL PROGRAM FOR THE LIQUIDATION OF PESTICIDE WASTE LANDFILLS, SUCCESSES AND UNUSED OPPORTUNITIES - CASE STUDY FROM POLAND
}

\author{
Department of Chemistry, Microbiology and Environmental Biotechnology, West Pomeranian \\ University of Technology, Szczecin, Poland \\ ${ }^{1}$ Department pf Horticulture, West Pomeranian University of Technology, Szczecin, Poland
}

\begin{abstract}
Previous generations (50-70's of the last century) left behind thousands of tons of toxic agrochemical waste (produced and stored for stock). Some of them have already been liquidated, but some have remained, because the costs of liquidation are enormous. In 2011, the national program for the liquidation of pesticide waste landfills ended (pesticide burial grounds with various chemicals types, organochlorine pesticides such as DDT, lindane, toxaphene, methoxychlor, heptachlor, $\alpha-\mathrm{HCH}, \beta-\mathrm{HCH}$ and phosphoroorganic pesticides, carbamate insecticides, dinitrophenols, phenoxyacids). The necessity of liquidation about 240 pesticide burial grounds (approx. $20000 \mathrm{Mg}$ obsolete pesticides) located throughout the country resulted from the obligations of Poland ratifying in 2008 the provisions of the Stockholm Convention on Persistent Organic Pollutions. The preparations and packaging were taken to the operated hazardous waste incineration plants. Debris and soil adjacent to the burial grounds were placed in hazardous waste landfills. After 6 years since the end of the national program for the decommission of burials, it is time for summarizing. Due to the fact that similar objects can be found in many countries around the world, analysis of the Polish case may be useful. The publication focuses not on the methods of utilization and statistical data, but on a critical look at the applied solutions, also presenting alternative solutions (mainly in situ and ex situ bioremediation), instead of storage.
\end{abstract}

Key words: obsolete pesticides, hazardous waste management, biodegradation.

\section{INTRODUCTION}

Among the many groups of hazardous waste, defined by the Act on Waste of 14 December 2012 (OJ 2013 pos. 21) (resulting from the Directive 2008/98/EC of the European Parliament and of the Council of 19 November 2008 on waste and repealing certain Directives), pesticide waste deserve special attention. Pesticide wastes are useless plant protection products (outdated or disqualified on the bases of qualitative research) and waste packaging plant protection products, contaminated protective clothing, contaminated soil, water and plant material (Castillo et al. 2008; Gałuszka et al. 2011). Active ingredients of pesticides inherently have the properties described in the Annexes to the Act on Waste, namely, are irritating (Annex 3, properties code $\mathrm{H} 4$ ) and/or toxic $(\mathrm{H} 5)$ and/or harmful $(\mathrm{H} 6)$ for selected groups organisms and/or ecotoxic $(\mathrm{H} 14)$. These properties determine the affiliation of

Corresponding Author: Magdalena Błaszak, Department of Chemistry, Microbiology and Environmental Biotechnology, West Pomeranian University of Technology, Szczecin, Juliusza Słowackiego 17, 71-434 Szczecin, Poland, e-mail: Magdalena.Blaszak@zut.edu.pl 
obsolete pesticides to hazardous waste. Disposal of hazardous waste is a procedure more expensive and more complicated formally. Disposal of obsolete or defective preparations and packaging is made through the use of thermal or chemical processes and biological and chemical methods are applied to materials contaminated with a lower dose of chemicals, for example, post-production washings, leachates from landfills and contaminated soil (Martínez 2004; Castillo et al. 2008). Biological methods for cleaning environmental matrices of pollution is the cheapest variant of waste recovery. Plant protection products are a diverse group of chemicals, however, microorganisms also make a huge pool of cells with varied properties (Schulz et al. 2013). Many isolated strains of microorganisms are capable of efficient biodegradation of several active ingredients of pesticides (Fang et al. 2010; Ortega et al. 2011; El-Bestawy et al. 2014). Theoretically, they are ideal for biodegradable pesticide residues in soil and water, but has their potential any practical results?

In the 1960s (following the instructions of the Central Union of Cooperative Farmers in Warsaw - the communist formation) facilities for storage of obsolete pesticides were formed (about 400 facilities across the country). Placement of burial grounds in random places without hydrogeological research and defective construction has led to a situation where burials have become a real threat to groundwater in all regions of the country. Pesticides (including permanently hazardous to health: lindane, DDT, hexachlorobenzene, aldrin, dieldrin and their metabolites), floated to the surface and underground waters over time and accumulated in the food chain to reach consumers of first and second order (Wołkowicz et al. 2003; Waleczek et al. 2007; Ignatowicz 2009). By ratifying the Stockholm Convention (which established a ban on the use and warrant of elimination of persistent organic pollutants POPs from the environment), Poland committed to elimination of pesticides landfills, in the majority of which, the pesticides classified as POPs were detected. The deadline for total elimination of the burial grounds expired at the end of 2010. In the Uchwała nr 217 Rady Ministrów z dnia 24 grudnia 2010 r. w sprawie „Krajowego planu gospodarki odpadami 2014 r." it was also expected to deal with the action of destroying the waste by the end of 2010. The National Fund for Environmental Protection and Water Management in Warsaw launched a priority program „Reclamation of degraded areas and the elimination of sources of particularly negative impact on the environment", whose one of the four tasks was "Elimination of landfills containing obsolete pesticides".

More than a dozen, and tens of thousands tonnes of pesticide waste are deposited in arrears in various countries all around the world (for example in Zambia, Ethiopia, Tunisia, Mali, Tanzania, Russian Federation, Pakistan, Uzbekistan, Tajikistan, Ukraine, Bulgaria) Vijgen and Egenhofer (2009); El-Shahawy and Simeonov (2013). Poland is an example of a country that has experienced the way towards permanent pesticide burial problem solving in direction: right and improper.

\section{THE NATIONAL PROGRAM ELIMINATION OF LANDFILLS CONTAINING OBSOLETE PESTICIDES AND RESTORATION OF THE AREA AFTER BURIAL GROUNDS AND SOIL BIOREMEDIATION}

The national program "Elimination of landfills containing obsolete pesticides" was successfully completed in 2011 . Over $98 \%$ of localized pesticide tombs have been liquidated (about 300 burial grounds and warehouses). The few remained, which due to logistical 
reasons or the complicated legal situation of the land, were planned for liquidation at a later date. Not all of the archived pesticide tombs were found or such ones were found in reference of which there was nothing mentioned in the documentation. Pesticide tombs were situated in various locations, most often in the forests, meadows, wastelands, bunkers from World War II, concrete wells, underground pits, basements of military facilities (Gałuszka et al. 2011) - Fig. 1.
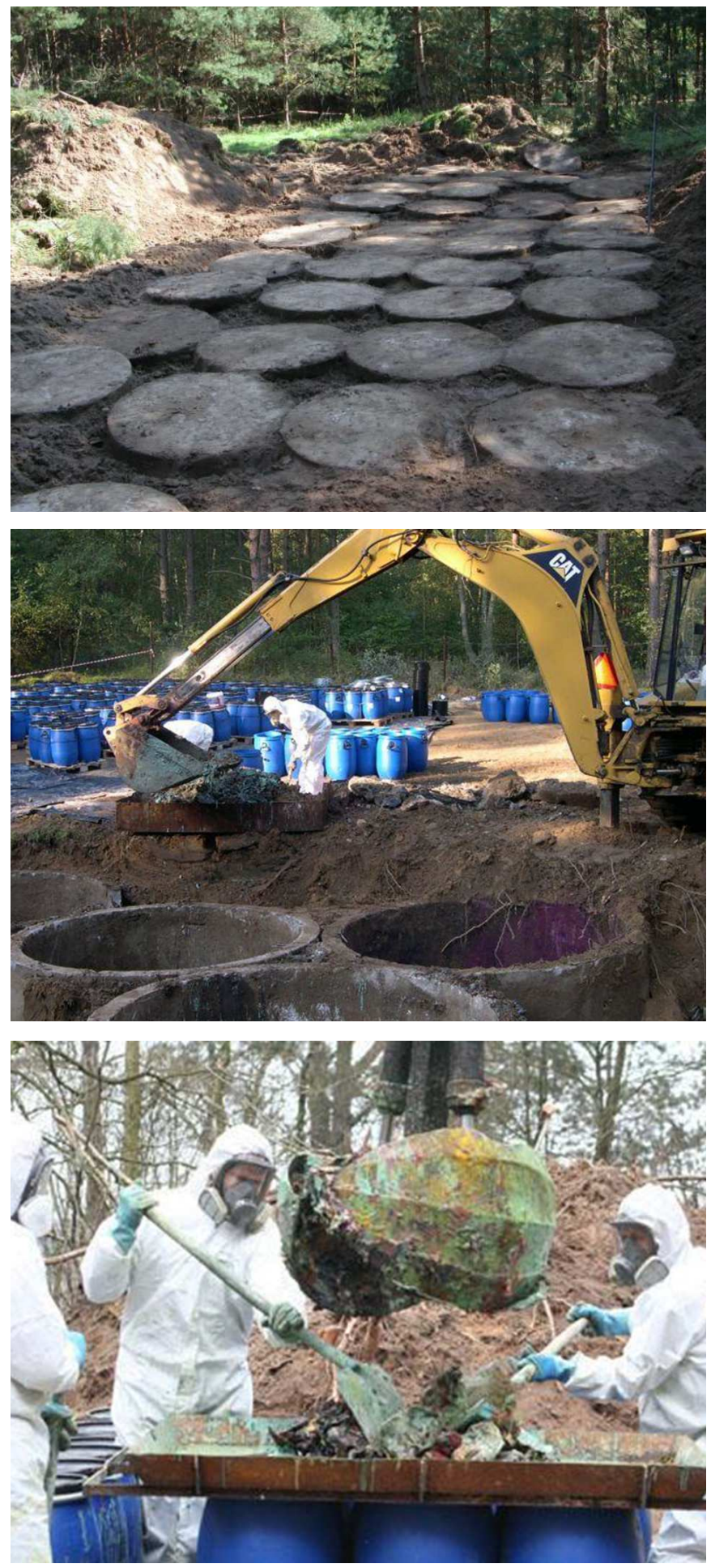

Fig. 1. Liquidation of burial grounds near the villages Tuchomie (Pomerania province) Source: property of Hydrogeotechnika, http://www.hydrogeotechnika.pl/. 
Liquidation of the pesticide tombs started in 1999, but the activities were of limited scope. The reason for the excessive length of work was the lack of a hazardous waste incineration plant in Poland, and thus the high costs of waste disposal abroad. Only after launching in 2003 a modern hazardous waste incineration plant in Dąbrowa Górnicza (50¹9'17"N $\left.19^{\circ} 11^{\prime} 14 " \mathrm{E}\right)$, the program of pesticide waste disposal definitely accelerated.

In total, over $76.500 \mathrm{Mg}$ pesticide wastes were disposed, including approximately $19.500 \mathrm{Mg}$ of the preparations, packaging, and the rest consisted of the soil and debris (Gałuszka et al. 2011; Raport Najwyższej Izby Kontroli 2012). After liquidation of over two hundred burial grounds throughout the country, specialized securing and transportation of preparations and their packaging to hazardous waste incineration plants in Gdansk and Dąbrowa Górnicza, the reclamation action has been taken.

According to the guidelines of the Ministry of the Environment on the Elimination of burial grounds (Guidelines for pesticide tomb removal and remediation of areas affected by obsolete pesticide disposal - Ministry of the Environment 2009), transported material (preparations, concrete elements and ground) was replaced by sandy soil mixed with clay, placed on the insulating layer of clay or loam. The surface layer of the soil was enriched with peat and area leveling was made. Structural elements of burial grounds and soil adjacent to the burials were transported to landfills of hazardous waste. Methods for biodegradation of pollutants using microorganisms was not used to the contaminated soil exported to landfills of hazardous waste. Many research and industrial experience show that introducing the microorganisms to the contaminated medium considerably accelerates the time of pollutants biodegradation, even those considered permanently lingering in the environment (Beaudette et al. 2000; Piekarska 2003; Kamanavalli and Ninnekar 2004; Fang et al. 2010; Ghosh et al. 2010; Ortega et al. 2011; Baczyński 2012).

Meanwhile, tens of thousands of tons of ground adjacent to the burials with varying degrees of pollution, were transported only to the landfills of hazardous waste (of course better than they would further spread unprotected in forests and meadows). Storage of ground only partially solved the problem, because contamination is still not eliminated, instead moving it to another place. The hierarchy of the waste handling (Directive 2008/98/EC of the European Parliament and of the Council of 19 November 2008 on waste and repealing certain Directives; Ustawa $z$ dnia 14 grudnia 2012 r. o odpadach) assumes in the first place activities related to the recovery of waste; in this case it may be a treatment on the land surface that brings improvement of the environment status R10 or soil cleaning leading to soil recovery R3 or reclamation of other inorganic materials R5. Storage is a finality if there is no alternative. It seems that the ex situ bioremediation of ground masses contaminated with pesticides would be the alternative to disposal (Baczyński and Małachowska-Jutsz 2010). Obviously, the investment would not be easy to carry out, because soils from various burial grounds were contaminated to varying degrees (there were also unpolluted soil), and the need for a point to carry out the remediation of soil mass in each province would involve costs. However, estimation of burial grounds liquidation analysis shows that almost half of the total investment was destined for disposal (storage) of ground. Contaminated ground material, instead of transport to the landfill, could be directed to the specialized units of soil recovery. This action not only would remove the problem of burial grounds, but also contaminated earth masses. Redirecting funds for the organization of units carrying out the reclamation of land is a comprehensive solution to the problem of pesticide 
waste, as well as other current pollutants. The largest number of burial grounds in Poland was established in Western Pomerania province (39 burial grounds in area $22892,48 \mathrm{~km}^{2}$ ), where the most state-owned farms (PGR) were established (Fig. 2).

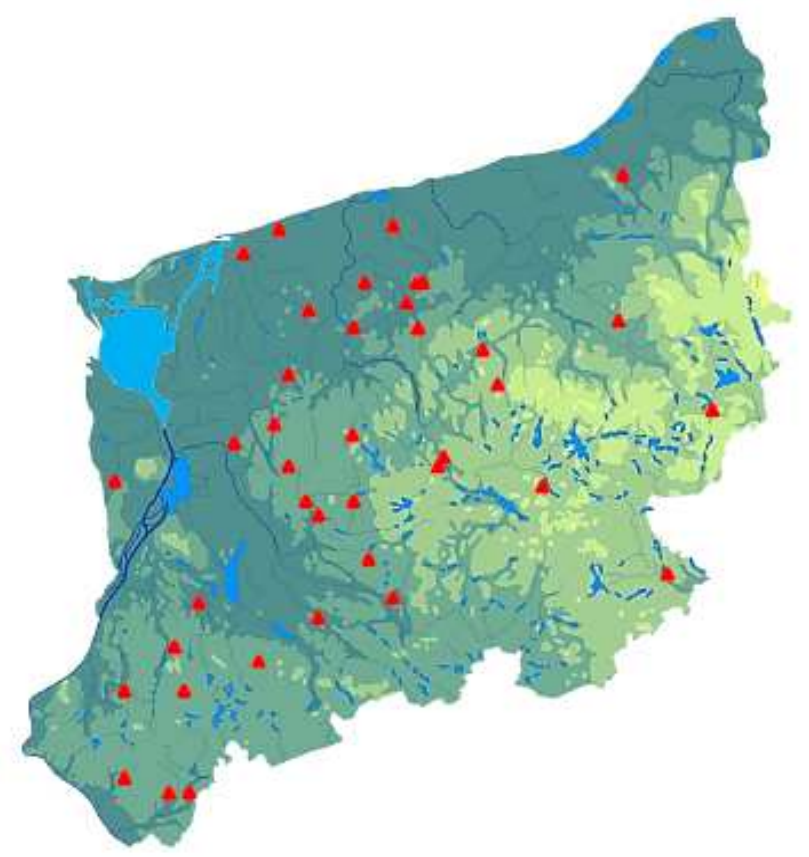

Fig. 2. The indicative distribution of burial grounds in Western Pomerania (39 burial grounds in area $22892,48 \mathrm{~km}^{2}$ ). Own study on the contour map acquired from Wikimedia Commons

Source: Mapa wód i ukształtowania powierzchni województwa zachodniopomorskiego, https://pl.wikipedia.org/ /wiki/Plik:Zachodniopomorskie_mapa_fizyczna.png.

Analysis of data from the project of liquidation the burial ground in Wisławie (Western Pomerania Province, 53 $30^{\prime} 46^{\prime \prime} \mathrm{N} 15^{\circ} 04^{\prime 22}$ "E) (Długosz 2009) confirms the above notices. Although during inventory work, the contamination of land around the burial chambers was not documented, export of potentially contaminated land $(690 \mathrm{Mg})$ to a hazardous landfill was planned, which entailed costs over 500000 PLN for the storage only (approximately 150000 USD) - Table 1. This sum relates to only one burial ground, and approx. 200 of them were liquidated in Poland.

Table 1. The costs of liquidation the burial grounds and land reclamation on the example of burial grounds in Wisławie (West-Pomeranian province). Own study based on a project, it was commissioned by Commune Maszewo

\begin{tabular}{lcc}
\hline \multicolumn{1}{c}{ Particular unit tasks } & $\begin{array}{c}\text { Weight of material } \\
{[\mathrm{Mg}]}\end{array}$ & $\begin{array}{c}\text { Cost for the task } \\
\text { completion [PLN] }\end{array}$ \\
\hline $\begin{array}{l}\text { Design and documentation works, obtaining the } \\
\text { administrative decisions, reporting }\end{array}$ & - & 18800 \\
\hline Special packaging, transportation, clothing, foils & - & 58000 \\
\hline Soil to fill the pits & 960,0 & 38000 \\
\hline Transport of pesticides & 63,8 & 19800 \\
\hline Transport of contaminated rubble & 130,6 & 6300 \\
\hline Transport of contaminated ground & 690,0 & 31500 \\
\hline Pesticide disposal - incineration & 63,8 & 223300 \\
\hline Rubble disposal (storage on landfill of hazardous waste) & 130,6 & 97950 \\
\hline Ground disposal (storage on landfill of hazardous waste) & 690,0 & 517500 \\
\hline Monitoring of contaminants & - & 13500 \\
\hline Total cost & & 1121650 \\
\hline
\end{tabular}

${ }^{a}$ Currency conversions according to Polish National Bank (NBP) 27.12.2017. 1 USD = 3.53 PLN.

Source: Długosz (2009). 


\section{THE PROBLEM OF PESTICIDE WASTE IN POLAND NOW}

Presently it can be concluded that the vast majority of content located in landfills was thermally disposed, except in cases - three pesticide tombs with $200 \mathrm{Mg}$ toxic waste (data from the year 2016) (Raport Najwyższej Izby Kontroli 2012; Uchwała nr 88 Rady Ministrów z dnia 1 lipca 2016 r. w sprawie „Krajowego planu gospodarki opadami 2022”). In Poland, only since about a decade, incineration plants of hazardous waste capable of disposing pesticide waste and protecting the current needs of hazardous waste disposal have operated. After the liquidation of burial grounds and storage with useless plant protection products, the issue of mass retention of chemicals in the environment has been largely resolved. Only not found burial grounds, that appear in the archives and were not located during the decommissioning program, have left. Due to the high costs of pesticides purchase, the general availability and efficient organization of receiving the packaging by the manufacturer, the cases of storing these means "for future", is not observed at present (Waleczek and Stobiecki 2011). The landfill „Rudna Góra” at the „Organika Azot” Chemical Plant in Jaworzno $\left(50^{\circ} 10^{\prime} 45^{\prime \prime} \mathrm{N} 19^{\circ} 14^{\prime} 45^{\prime \prime} \mathrm{E}\right)$ is still the biggest pesticide problem, because nearly $160000 \mathrm{Mg}$ of pesticide waste and contaminated soil are deposited. The old landfill was created about 60 years ago. Huge financial resources necessary for the liquidation of the landfill are not currently available, and court proceedings-administrative about appoint liquidator pollution is very complicated. Due to the location within the Vistula River catchment, it is so-called "hot point" to the Helsinki Convention on the Baltic Sea waters protection (pos. 89 on the list) - Waleczek (2006); Błaszak et al. (2011); Gałuszka (2011).

\section{SOIL MICROORGANISMS - THE ENZYMATIC ACTIVITY POTENTIAL}

Every year, pesticides end up in agricultural soils in Poland in amounts of about $2000 \mathrm{Mg}$ per active substances (Rocznik Statystyczny Rolnictwa 2013). Over time, the level of substances introduced into the soil decreases, until undetectable. This is due to the natural physical and biochemical processes occurring in the environment. By optimizing the processes of microbial degradation of pesticides, it can be led to accelerated natural transformation of pesticides in the environment (Ralebitso et al. 2002; Porto et al. 2011). Biological methods of pesticides disposal are applicable only to materials (mainly sewage, water and soil) and not the preparations themselves. Organic pesticides entering the environment (as a result of agricultural operations) are mostly converted by microorganisms in order to obtain macronutrients and/or energy source. However, pesticides may also disappear from the environment as a result of co-metabolic changes, when their decomposition is not needed to microorganisms, and it is only a consequence of the active substance adjustment to the active center of the enzyme. In general, co-metabolic changes transform the substrate to a small degree, but these minute changes open the way for other microorganisms to further transformation of a xenobiotic (MacRae 1989; Różański 1992). Microorganisms inhabit all natural ecosystems on our planet. They can be detected both in soils, water, air, and in the desert sands, or in hydrothermal vents on the ocean floor, in Arctic glaciers, in and on the organisms. The prevalence of bacteria, fungi, archaea, and viruses is associated with 
a variety of nutrients and energy gaining strategies, as well as adaptive mechanisms that have been evolved in the course of evolution (Schopf 2001; Błaszczyk 2009, 2010; Dzik 2011). The rate of reproduction, genetic variation, diasotrophy, or mixotrophy are just some of the properties making microorganisms resistant to adverse conditions.

Bacteria and fungi, playing the role of reducents in the food chain, convert the organic matter starting from decomposition of high-molecular organic compounds such as starch, cellulose, glycogen, lignin, peptidoglycan, chitin etc., and ending with the mineralization of organic monomers. Products of mineralization are used by plants and other soil organisms incorporating them into their own cells (Eisenhauer et al. 2012; Bardgett and Putten 2014). Sooner or later, all the organic wastes that persist in the environment, are utilized by microorganisms, if not within months, then years or centuries. The greater variety of microorganisms, the more likely utilization of xenobiotics, even permanently backlogged in the environment (POPs) - Porto et al. (2011) - Table 2.

Table 2. Examples of microbial strains with a confirmed ability to biodegradation of organochlorine pesticides. Own study based on the review of other authors' works

\begin{tabular}{|c|c|c|}
\hline $\begin{array}{l}\text { Pesticides subjected to } \\
\text { biodegradation (to different degree) }\end{array}$ & $\begin{array}{l}\text { Microorganisms (isolate with } \\
\text { confirmed ability to biodegradation) }\end{array}$ & References \\
\hline DDT & $\begin{array}{l}\text { Aerobacter aerogenes } \\
\text { Trichoderma viridae } \\
\text { Pseudomonas sp. } \\
\text { Micrococcus sp. } \\
\text { Arthrobacter sp. } \\
\text { Bacillus sp. } \\
\text { Basea thiooxidans } \\
\text { Sphingobacterium sp. } \\
\text { Enterobacter aerogenes } \\
\text { Pseudomonas fluorescens } \\
\text { Escherichia coli } \\
\text { Klebsiella pneumoniae } \\
\end{array}$ & $\begin{array}{l}\text { Fang et al. (2010) } \\
\text { Wedemeyer (1966) } \\
\text { Patil et al. (1970) } \\
\text { Pesce and Wunderlin (2004) } \\
\text { Lal and Saxena (1982) }\end{array}$ \\
\hline DDD & $\begin{array}{l}\text { Trichoderma sp. } \\
\text { Ralstonia eutropha }\end{array}$ & $\begin{array}{l}\text { Hay and Focht (2000) } \\
\text { Ortega et al. (2011) }\end{array}$ \\
\hline Lindane & $\begin{array}{l}\text { Sphingomonas paucimobilis } \\
\text { Streptomyces sp. } \\
\text { Pleurotus ostreatus } \\
\text { (microbial consortium: } \\
\text { Sphingobacterium spiritivorum, } \\
\text { Ochrobactrum anthropi, Bosea } \\
\text { thiooxidans, Sphingomonas } \\
\text { paucimobilis) }\end{array}$ & $\begin{array}{l}\text { Silva et al. (1999) } \\
\text { Pesce and Wunderlin (2004) } \\
\text { Rigas et al. (2005) } \\
\text { Benimeli et al. (2008) }\end{array}$ \\
\hline Heptachlor & $\begin{array}{l}\text { Phlebia sp. } \\
\text { Phanerochaete chrysosporium }\end{array}$ & $\begin{array}{l}\text { Arisoy and Kolankaya (1998) } \\
\text { Xiao et al. (2011) }\end{array}$ \\
\hline Aldrin & $\begin{array}{l}\text { Micrococcus sp. } \\
\text { Bacillus sp. } \\
\text { Trichoderma viridae } \\
\text { Pseudomonas sp. } \\
\text { Bacillus licheniformis } \\
\text { Escherichia coli }\end{array}$ & $\begin{array}{l}\text { Patil et al. (1970) } \\
\text { Diazgranados et al. (2012) } \\
\text { Yunhua and Fan (2012) }\end{array}$ \\
\hline
\end{tabular}

Conversion of organic matter occurs due to the biochemical processes catalyzed by enzymes such as: oxidoreductases, transferases, hydrolases, lyases, isomerases and others. With these "tools", microorganisms are able to use both natural and human-processed matter as a source of macronutrients and energy (Alves et al. 2014; Wyszkowska et al. 2016). This 
makes the microorganisms with the desired properties, after isolation from the environment and transformation onto the product (vaccine, inoculate), are used on an industrial scale for biodegradation of contaminants, e.g. petroleum substances, organic compounds in municipal and industrial wastewater, in the flue gas, as well as for the disposal of pesticide residues in the sewage or soil (Błaszczyk 2009).

\section{THE USE OF BIOLOGICAL METHODS FOR THE ELIMINATION OF PESTICIDE WASTE}

The main role in the disposal of hazardous waste and other obsolete pesticide play thermal methods: combustion in rotary kilns, furnaces cyclone, ventricular, fluidized bed, hydrogen plasma activity. Among the chemical methods: resolution by concentrated sulfuric acid, decomposition with the use of burnt lime, a reduction with hydrogen, Fenton reaction and photo-Fenton ozonisation, solidification by mixing with hydraulic cement and quicklime can be mentioned (Liberatore et al. 2012; Ebrahiem et al. 2017). However, the microbial methods for the purification of soil are more beneficial, cheaper, preferred (better recovery of contaminated soil than disposal) (Piekarska 2003; Błaszczyk 2009; Baczyński and Małachowska-Jutsz 2010; Baczyński 2012). Even persistent organic pollutants are under favorable conditions, biochemically transformed by microbial strains. Leachate from hazardous waste landfills can be subjected to bioremediation at the site of their generation by installing a bioreactor or cheaper versions of the system. Examples of the biological method use (in combination with other methods) to reduce pollution from leachate of pesticide landfills were transient installations accumulating the leachate and at the same time leading to reduction of contamination (Baczyński 2009, 2013).

As a result of securing the contaminated materials, i.e. rubble and soil coming from liquidated leaking burial grounds in Niedźwiady (Greater Poland province) and Sośnicowice (Silesian province), open chambers with rubble and contaminated soil and open containers for the effluents, have been formed. Washed contaminants with access to light and air, got degraded under the influence of natural physicochemical and biological processes (Waleczek et al. 2007).

Company Fregata S.A. in Gdansk (production division in Waćmierz) had used the biological technology - inactivating washings and pesticide residues by means of biological method in bioreactor with fixed active bed to clean the industrial wastewater. Installing, converting $550 \mathrm{Mg}$ waste annually, is effective, simple and above all safe for the environment (Błaszak et al. 2011). Knowing the composition of washings (in the factory - as opposed to the landfill - the variety of chemicals is small), it can be easier to fit the appropriate composition of the vaccine. Isolates of the following genera: Pseudomonas, Arthrobacter, Agrobacterium, Rhodococcus, commonly present within the environment, biodegrade most of the active substances in pesticides under optimal conditions in tens-hundreds of hours (Ralebitso et al. 2002). High potential characterizes bacteria of the activated sediment, which suitably selected and used, simultaneously decompose several pesticides. For example, a mixture of substances alachlor, atrazine, chlorfenvinphos, diuron, and isoproturon was oxidized using the photo-Fenton reaction and then treated with activated sediment bacteria. The high share of the biological part in the whole process (as compared to chemical phase) ensured lower technological costs (Liberatore et al. 2012). 
Very simple and cheap way to "green" disposal of chemical contamination on farms was proposed by constructing a stand to service the sprayers called BioBed according to the concept by Castillo and Torstensson (Castillo et al. 2008). The mixture of soil, peat and straw filling the concrete chamber dug in the ground, covered with grasses on surface, takes washings generated from washing, filling and using the sprayer that is in this stand. The effluents from the chamber are collected in a separate container, the content of which is returned to the purification system in a timely manner.

\section{CONCLUSION}

With the ratification of the Stockholm Convention (which resulted from the signing of the Accession Treaty) and the commitment to ridding the persistent organic pollutants off the environment (term of commitments expired at the end of 2010), it was taken in Poland an effective action to eliminate more than two hundred burial grounds and landfills of useless pesticides. Currently in Poland, there is no problem of burial grounds or it is marginal. The pesticide waste landfill "Rudna Góra” at the "Organika Azot” Plant in Jaworzno (pos. No. 89 on the list of so-called "hot spots" of the Helsinki Convention on the protection of the Baltic Sea waters) is still a source of the largest chemical contamination of the environment in Poland. For several years the corrective action is undertaken, but the extent of pollution is so large - several hectares is the central landfill - that so far the problem was not handled. Proven potential of environmental microorganisms in the decomposition of many active substances in pesticides (including certain POPs) has not been used during implementation of the national project entitled "Liquidation of burial grounds containing the expired pesticides". Tens of thousands of tons of ground adjacent to the burials, with varying degrees of contamination, were transported only to landfills for hazardous waste. The ground storage only partially solved the problem, because the contamination is still not eliminated, while moved to another place.

\section{REFERENCES}

Alves P.D., Siqueira F.F., Facchin S., Horta C.C., Victória J.M., Kalapothakis E. 2014. Survey of microbial enzymes in soil, water, and plant microenvironments. Open Microbiol. J. 8, 25-31.

Arisoy M., Kolankaya N. 1998. Biodegradation of heptachlor by Phanerochaete chrysosporium ME 446: The toxic effects of heptachlor and its metabolites on mice. Turkish J. Biol. 22, 427-434.

Baczyński T. 2009. Solid phase anaerobic bioremediation of soil from the "tomb" area contaminated with chlorinated pesticides. Arch. Environ. Prot. 35(3), 123-133.

Baczyński T. 2012. Influence of process parameters on anaerobic biodegradation of ddt in contaminated soil preliminary lab-scale study. Part I. surfactant and initial contamination level. Environ. Prot. Engin. 38(4), 113-125.

Baczyński T. 2013. Influence of process parameters on anaerobic biodegradation of DDT in contaminated soil. Preliminary lab-scale study. Part II. Substrates and pH control. Environ. Prot. Engin. 39(1), 5-16.

Baczyński T., Małachowska-Jutsz A. 2010. Remediacja gruntów skażonych odpadami pestycydów chloroorganicznych, w: Rekultywacja i rewitalizacja terenów zdegradowanych. Red. G. Malina. Poznań, PZITS, 7-17. [in Polish]

Bardgett R.D., Putten W.H. 2014. Belowground biodiversity and ecosystem functioning. Nature 515, 505-511. 
Beaudette L.A., Ward O.P., Pickard M.A., Fedorak P.M. 2000. Low surfactant concentration increases fungal mineralization of a polychlorinated biphenyl congener but has no effect on overall metabolism. Lett. Appl. Microbiol. 30,155-160.

Benimeli C.S., Fuentes M.S., Abate C.M., Amoroso M.J. 2008. Bioremediation of Lindane-Contaminated Soil by Streptomyces sp. M7 and its Effects on Zea mays Growth. Int. Biodeterior. Biodegrad. 61, 233-239.

Błaszak M., Pełech R., Graczyk P. 2011. Screening of microorganisms for biodegradation of simazine pollution (Obsolete Pesticide Azotop 50 WP). Water Air Soil Pollut. 220, 373-385.

Błaszczyk M. 2010. Mikrobiologia środowisk. Warszawa, PWN. [in Polish]

Błaszczyk M. 2009. Mikroorganizmy w ochronie środowiska. Warszawa, PWN. [in Polish]

Castillo M.P., Torstensson L., Stenström J. 2008. Biobeds for environmental protection from pesticide use. A review. J. Agric. Food Chem. 56(15), 6206-6219.

Diazgranados S., Gregorio J., Lopez H., Andres C. 2012. Degradation of aldrin by Bacillus licheniformis, isolated from water and sediment from the Ciénaga Grande, Santa Marta, Colombia. Acta Biol. Colomb. 17(1), 67-76.

Directive 2008/98/EC of the European Parliament and of the Council of 19 November 2008 on waste and repealing certain Directives. DzU UE 22.11.2008, L 312/3.

Długosz A. 2009. Projekt likwidacji mogilnika Wisławie i rekultywacji terenu po zlikwidowanym mogilniku. Przedsiębiorstwo Geologiczne Sp. z o.o., http://bip.rbip.wzp.pl/sites/bip.wzp.pl/files/articles/ 1090922140115.pdf, access: 27.12.2017. [in Polish]

Dzik J. 2011. Historia życia na Ziemi. Warszawa, PWN. [in Polish]

Ebrahiem E.E., Al-Maghrabib M.N., Mobarkia A.R. 2017. Removal of organic pollutants from industrial wastewater by applying photo-Fenton oxidation technology. Arab. J. Chem. 10, 1674-1679.

Eisenhauer N., Reich P.B., Isbel F. 2012. Decomposer diversity and identity influence plant diversity effects on ecosystem functioning. Ecology 93(10), 2227-2240.

El-Bestawy E., Mansy A.H., Attia A.M., Zahran H. 2014. Biodegradation of persistent chlorinated hydrocarbons using selected freshwater bacteria. J. Bioremed. Biodeg. 5, 226.

El-Shahawy A., Simeonov L.I. 2013. Environmental and health situation with obsolete pesticides in Egypt, in: Environmental security assessment and management of obsolete pesticides in Southeast Europe. Ed. Simeonov L., F. Macaev, B. Simeonova. NATO Science for Peace and Security Series C: Environmental Security. Dordrecht, Springer.

Fang H., Dong B., Yan H., Tang F., Yunlong Y. 2010. Characterization of a bacterial strain capable of degrading DDT congeners and its use in bioremediation of contaminated soil. J. Hazard Mater. 184(1-3), 281-289.

Gałuszka A., Migaszewski Z.M., Manecki P. 2011. Pesticide burial grounds in Poland. A review. Environ. Int. 37, 1265-1272.

Ghosh P.G., Sawant N.A., Patil S.N., Aglave B.A. 2010. Microbial biodegradation of organophosphate pesticides. Int. J. Biotechnol. Biochem. 6(6), 871-876.

Hay A.G., Focht D.D. 2000. Transformation of 1,1-dichloro-2,2-(4-chlorophenyl) ethane (DDD) by Ralstonia eutropha strain A5. FEMS Microbiol. Ecol. 31, 249-253.

Ignatowicz K. 2009. Badania rozpoznawcze możliwości zastosowania fitoremediacji do ochrony terenów wokół mogilników pestycydowych [Exploratory study upon possibility of using the phytoremediation to protect land around the pesticide burial grounds]. Środ. Pom. Tow. Nauk Ochr. Środ. 11(73), 1007-1016. [in Polish]

Kamanavalli C.M., Ninnekar H.Z. 2004. Biodegradation of DDT by a Pseudomonas Species. Curr. Microbiol. 48(1), 10-13.

Lal R., Saxena D.M. 1982. Accumulation metabolism, and effects of organochlorine insecticides on microorganisms. Microbiol. Rev. 46(1), 95-127.

Liberatore L., Bressan M., Belli C., Lustrato G., Ranalli G. 2012. Chemical and biological combined treatments for the removal of pesticides from wastewaters. Water Air Soil Pollut. 223, 4751. 
MacRae I.C. 1989. Microbial metabolism of pesticides and structurally related compounds. Rev. Environ. Contam. Toxicol. 109, 1-87.

Mapa wód i uksztaltowania powierzchni województwa zachodniopomorskiego, https://pl.wikipedia.org/ /wiki/Plik:Zachodniopomorskie_mapa_fizyczna.png, access: 10.09.2018. [in Polish]

Martínez J. 2004. Practical guideline on environmentally sound management of obsolete pesticides, in: Basel convention coordinating centre for Latin America and the Caribbean Country. Network of centres. Ed. S. Aguinaga. Montevideo, Uruguay, http://archive.basel.int/centers/proj_activ/ /tctf_projects/013.pdf, access: 10.09.2018.

Ortega N.O., Nitschke M., Mouad A.M., Landgraf M.D., Rezende M.O.O., Seleghim M.H.R., Sette L.D., Porto A.L.M. 2011. Isolation of Brazilian marine fungi capable of growing on DDD pesticide. Biodegradation 22, 43-50.

Patil K.C., Matsumura F., Boush G.M. 1970. Degradation of endrin, aldrin, and DDT by soil microorganisms. J. Appl. Microbiol. 19(5), 879-881.

Pesce S.F., Wunderlin D.A. 2004. Biodegradation of lindane by a native bacterial consortium isolated from contaminated river sediment. Int. Biodeterior. Biodegradation 54(4), 255-260.

Piekarska K. 2003. Biodegradacja polichlorowanych bifenyli przez zespół mikroorganizmów wyizolowanych $z$ wody i gleby [Biodegradation of polychlorinated biphenyls by a team of microorganisms isolated from water and soil]. Ochr Środ. 25(2), 21-27. [in Polish]

Porto A.L.M., Melgar G.Z., Kasemodel M.C., Nitschke M. 2011. Biodegradation of pesticides, in: Pesticides in the modern world - pesticides use and management. Ed. M. Stoytcheva. Croatia, InTech.

Ralebitso T., Senior E., Verseveld H. 2002. Microbial aspects of atrazine degradation in natural environments. Biodegradation 13,11-19.

Raport Najwyższej Izby Kontroli. 2012. Realizacja "Krajowego planu gospodarki odpadami 2010" w zakresie likwidacji mogilników. [in Polish]

Rigas F., Dritsa V., Marchant R., Papadopoulou K., Avramides E.J., Hatzianestis I. 2005. Biodegradation of lindane by Pelourotus ostreatusvia Central Composite Design. Environ. Int. 31(2), 191-196.

Rocznik Statystyczny Rolnictwa. 2013. Warszawa, GUS. [in Polish]

Różański L. 1992. Przemiany pestycydów w organizmach żywych i środowisku. Warszawa, PWRiL. [in Polish]

Schopf J.W. 2001. Cradle of life the discovery of earth's earliest fossils. New Jersey, Princeton University Press.

Schulz S., Brankatschk R., Dumig A., Kogel-Knabner I., Schloter M., Zeyer J. 2013. The role of microorganisms at different stages of ecosystem development for soil formation. Biogeosciences 10 , 3983-3996.

Silva F.C., Cardeal Z.L., De Carvalho C.R. 1999. Determination of organophosphorus pesticides in water using SPME-GC-MS. Quím Nova 22(2), 197-200.

Uchwała nr 217 Rady Ministrów z dnia 24 grudnia 2010 r. w sprawie „Krajowego planu gospodarki odpadami 2014". MP z 2010 r., nr 101, poz. 1183. [in Polish]

Uchwała nr 88 Rady Ministrów z dnia 1 lipca 2016 r. w sprawie „Krajowego planu gospodarki odpadami 2022". MP z 2016 r., poz. 784. [in Polish]

Ustawa z dnia 14 grudnia 2012 r. o odpadach. DzU z 2013 r., poz. 21. [in Polish]

Vijgen J., Egenhofer C. 2009. Obsolete (lethal) pesticides, a ticking time bomb and why we have to act now. Holte, IHPA.

Waleczek K. 2006. Redukcja ryzyka związanego z produkcją, dystrybucją i stosowaniem środków ochrony roślin, w: Ryzyko ze strony odpadów pestycydowych. Sympozjum IOR, Poznań 12.12.2016. Poznań, IOR. [in Polish]

Waleczek K., Stobiecki T. 2011. Uwolnienie Polski od problemu odpadów pestycydowych [Polish release from the problem of pesticide waste]. Chemia Zdrowie Środ. 2, 9-11. [in Polish] 
Waleczek K., Stobiecki T., Giza I. 2007. Analiza zaniku skażeń terenu wokół zlikwidowanych mogilników [Analysis of the contamination disappearance of area around liquidated burial grounds]. Prog. Plant Prot. 47(4), 102-110. [in Polish]

Wedemeyer G. 1966. Dechlorination of DDT by Aerobacter aerogenes. Science 152(3722), 647.

Wołkowicz S., Wołkowicz W., Choromański D. 2003. Research on the influence of overdue plant pesticides (burial grounds) on geological environment (stage 3). Warszawa, National Geological Institute.

Wyszkowska J., Tomkiel M., Baćmaga M., Borowik A., Kucharski J. 2016. Response of microorganisms and enzymes to soil contamination with a mixture of pethoxamid terbuthylazine. Environ. Earth Sci. 75, 1285.

Wytyczne określające sposób prowadzenia działań polegających na likwidacji mogilników i rekultywacji terenów zdegradowanych składowaniem przeterminowanych środków ochrony roślin - według stanu prawnego na dzień 30 kwietnia 2009 r. Warszawa, Ministerstwo Środowiska. [in Polish]

Xiao P., Mori T., Kamei I., Kondo R. 2011. Metabolism of organochlorine pesticide heptachlor and its metabolite heptachlor epoxide by white-rot fungi, belonging. to genus Phlebia. FEMS Microbiol. Lett. 314(2), 140-146.

Yunhua W., Fan Y. 2012. Biodegradation of aldrin by recombinant Escherichia coli Expressing House Fly Cytochrome P450 6A1. J. S.-Cent. Univ. Natl. 2, 29-32.

\section{KRAJOWY PLAN LIKWIDACJI MOGILNIKÓW I ODPADÓW PESTYCYDOWYCH, SUKCESY I NIEWYKORZYSTANE MOŻLIWOŚCI - STUDIUM PRZYPADKU Z POLSKI}

Streszczenie. Poprzednie pokolenia Polaków (lata 50-70 ubiegłego wieku) pozostawiły po sobie tysiące ton toksycznych odpadów agrochemicznych. W 2011 roku w Polsce zakończył się krajowy program likwidacji składowisk odpadów pestycydowych zawierających toksyczne związki, np.: DDT, lindan, aldryna, toksafen, metoksychlor, heptachlor, $\alpha-\mathrm{HCH}, \beta-\mathrm{HCH}$, pestycydy fosforoorganiczne i karbaminianowe, dinitrofenole. Konieczność likwidacji rozmieszczonych w całym kraju ponad 240 historycznych składowisk tych odpadów (zawierających ok. $20000 \mathrm{Mg}$ pestycydów i opakowań) wynikała z międzynarodowych zobowiązań Polski (konwencja sztokholmska). Najszybszym rozwiązaniem jest termiczne unieszkodliwienie odpadów w specjalistycznych instalacjach (w spalarniach odpadów niebezpiecznych). Natomiast w odniesieniu do zanieczyszczonej gleby i wody z powodzeniem można zastosować metody biologicznego rozkładu polutantów. Potencjał enzymatyczny bakterii i grzybów jest duży, chociaż ograniczony wysokim poziomem skażenia matrycy. Dzięki pracom likwidacyjnym większość mogilników została zlikwidowana (w latach 1999-2011). Preparaty i opakowania wywieziono do uruchomionej w kraju spalarni odpadów niebezpiecznych, a gruz i glebę sąsiadującą z mogilnikami umieszczono na składowiskach odpadów niebezpiecznych. Po 7 latach od zakończenia krajowego programu likwidacji mogilników i magazynów agrochemikaliów czas na podsumowania. W związku z tym, że podobne obiekty występują $w$ wielu krajach, analiza polskiego przypadku może być przydatna. W publikacji skupiono się nie na samych metodach utylizacji i danych statystycznych, ale na krytycznym spojrzeniu na zastosowane rozwiązania, przedstawiając też rozwiązania alternatywne w odniesieniu do składowania.

Słowa kluczowe: odpady pestycydowe, zarządzanie gospodarką odpadami niebezpiecznymi, biodegradacja. 